\title{
ADA Gene
}

National Cancer Institute

\section{Source}

National Cancer Institute. ADA Gene. NCI Thesaurus. Code C30156.

This gene is involved in nucleotide metabolism and cellular immunity. 